\title{
The Effect of Detritus Ration on Metal Transfer to Deposit-Feeding Benthos
}

\author{
Donald L. Rice*, Kenneth R. Tenore and Herbert L. Windom \\ Skidaway Institute of Oceanography, P. O. Box 13687, Savannah, Georgia 31406, USA
}

\begin{abstract}
The quantity of organic detritus available for ingestion may significantly affect minor and trace metal concentrations in populations of benthic deposit feeders. Laboratory populations of the polychaete Capitella capitata Fabricius were maintained at 3 rations of each of 2 seaweed detritus. Concentrations of $\mathrm{Rb}, \mathrm{Cu}, \mathrm{Ag}, \mathrm{Zn}, \mathrm{Cd}, \mathrm{Ni}, \mathrm{Al}, \mathrm{Fe}$, and $\mathrm{Mn}$ in the worms were measured after population biomass increased. Copper (present at 'pollutant' levels in the system) concentrations also decreased with increasing ration, although the decreases were not significant. There were slight, statistically insignuficant increases in $\mathrm{Al}$, Fe, and $\mathrm{Mn}$ concentrations in the worms as ration increased. The decreases in uptake of metals other than $\mathrm{Al}, \mathrm{Fe}$, and $\mathrm{Mn}$ are attributed to increased reworking of the total benthic trace metal pool (food, sediments, water) by larger populations of C. capitata. Differences in rates of detrital input into benthic systems and the concomitant variation in benthic secondary production may significantly affect metal concentrations in natural populations of deposit feeders.
\end{abstract}

\section{INTRODUCTION}

As an abundant, chemically reactive and nutritious form of particulate matter, organic detritus is an important biogeochemical agent in the benthic environment. Organic detritus is a major food resource for detritusbased food chains and accounts for much of the benthic secondary production (Darnell, 1967; Mann, 1972: Tenore, 1976). Both the quantity and quality (i.e the organic nitrogen and available caloric content) of detritus affect trophic transfer to detritivores (Conover, 1962; Suschenya, 1970; Tenore and Gopalan, 1974; Tenore, 1981). Moreover, detritus derived from estuarine macrophytes may introduce substantial quantities of particulate minor and trace metals into the benthic environment for burial in the sediments or incorporation and recycling by benthic organisms (Odum and Drifmeyer, 1978; Rice, 1979). Consequently, in a biogeochemical perspective, organic detritus is not only a potential source of metals for the benthic environment, it is just as importantly the energetic base upon which production of living biolog-

\footnotetext{
- Present address: Department of Geological Sciences and Environmental Studies, State University of New York at Binghamton, Binghamton, New York 13901, USA
}

ical scavengers of metals (and other elements) depends.

Because of the central role of detritus in marine benthic systems, the quantity of detritus available for ingestion may affect metal concentrations in detritivores. Past studies have largely ignored the role of trophic energetics in metal uptake and recycling by marine organisms - a major shortcoming in light of the many advances in marine chemistry and ecology. Organisms derive their metal content from food, water, and sediments. The relative importance of each of these three sources is still a subject of much speculation so that generalizations, even for a single species, are presently unwarranted (Bryan, 1976; Jenne and Luoma, 1977). Field studies of metal uptake by marine benthos have often dealt with metal transfer from water or sediment in metal-polluted estuaries (Bryan and Hummerstone, 1971, $1973 \mathrm{a}, \mathrm{b}$; Ireland, 1973; Bryan, 1974; Valiela et al., 1974). Because of the complexity of the problem, such studies often appear to contradict one another; for example, Cross et al. (1970) found no relation between concentrations of heavy metals in sediments and infaunal polychaetes, while other investigators found the opposite to be true (Bryan and Hummerstone, 1971; Bryan, 1974). Our work suggests that these apparent contradictions may arise in 
part from differences in the quantity of detrital food available to different macroconsumer populations.

To offset the problems associated with field studies, the effects of detrital food quantity on metal uptake by populations of macroconsumers may be isolated and evaluated by laboratory studies. In this paper we present the results of a laboratory study of how the available quantity of two detrital foods derived from seaweeds affected the concentrations of nine metals in populations of the deposit-feeding polychaete Capitella capitata.

\section{MATERIALS AND METHODS}

Two detrital food stocks were prepared from the seaweeds Gracilaria foliifera var. angustissima and Ascophyllum nodosum. Healthy plants were rinsed with distilled water, oven dried at $80^{\circ} \mathrm{C}$, ground with a Wiley mill to pass a $120 \mu \mathrm{m}$ mesh sieve, and stored frozen until used. Organic carbon and nitrogen levels were determined with a Perkin-Elmer Elemental Analyzer (Model 240), and caloric content was determined with a Parr Microbomb Calorimeter. Estimates of 'available' caloric content were made by a dilute $\mathrm{HCl}$ hydrolysis technique (Tenore, 1981). Contents of $\mathrm{Rb}, \mathrm{Cu}, \mathrm{Ag}, \mathrm{Zn}, \mathrm{Cd}, \mathrm{Ni}, \mathrm{Al}, \mathrm{Fe}$, and $\mathrm{Mn}$ were determined by the method described below. Results of the chemical assay for the two detritus are given in Table 1.

Metal uptake experiments with Capitella capitata
Fabricius were carried out in $0.1 \mathrm{~m}^{2}$ plastic trays receiving $200 \mathrm{ml} \mathrm{min}{ }^{-1}$ of aerated, $1 \mu \mathrm{m}$-filtered, temperature regulated $\left(20^{\circ} \mathrm{C} \pm 1 \mathrm{C}^{\circ}\right)$ seawater The trays were layered $(2.5 \mathrm{~cm})$ with clean fine $(<0.3 \mathrm{~mm})$ sand. Details of the culture system design have been described previously (Tenore, 1977). After several initial additions of detritus, each of 12 trays received ca 30 C. capitata from our stock culture. Duplicate trays were maintained at different rations $(2.5,4.0$, or $5.5 \mathrm{~g}$ dry weight $\mathrm{m}^{-2} \mathrm{~d}^{-1}$ ) of each detritus for $90 \mathrm{~d}$. This period of time allows the initial population of 30 worms to grow to carrying capacity, e.g. 1000-2000 worms. Consequently the initial C. capitata biomass is but a small fraction of the final biomass. After $90 \mathrm{~d}$, each tray was sieved and the worms were carefully separated from sedimentary debris. Total wet weights of C. capitata in. each tray were recorded, and the worms from each tray were separated into three portions. One portion was dried and ashed for determination of ash-frce biomass. The other two portions were placed in filtered seawater and allowed to avoid their guts for $12 \mathrm{~h}$. These latter two worm subsamples from each tray were then quickly rinsed in double-distilled water, lyophilized, weighed, and wet-ashed in tightly capped Teflon bottles with reagent-grade concentrated nitric acid for determination of $\mathrm{Rb}, \mathrm{Cu}, \mathrm{Ag}, \mathrm{Zn}, \mathrm{Cd}, \mathrm{Ni}, \mathrm{Al}, \mathrm{Fe}$, and Mn by atomic absorption spectrophotometry (Windom and Cutshall, 1976). Nitric acid procedural blanks gave metal values which were negligible at the level of the analysis. As a test of analytical accuracy, samples of NBS Standard Reference Material 1571 (orchard leaves) were wet-ashed and analyzed by the

Table 1. Capitella capitata. Chemical assay of control (initial) stock and detrital foods. Analytical uncertainties are expressed as one standard deviation from the mean of three to six independent determinations

\begin{tabular}{|c|c|c|c|}
\hline Component & $\begin{array}{l}\text { Ascophyllum } \\
\text { Detritus }\end{array}$ & $\begin{array}{l}\text { Gracilaria } \\
\text { Detritus }\end{array}$ & $\begin{array}{l}\text { Capitella } \\
\text { Control }\end{array}$ \\
\hline \multicolumn{4}{|c|}{$\% \mathrm{C}, \mathrm{Ng}^{-1}$ dry weight } \\
\hline $\mathrm{C}$ & 33.3 & 31.8 & - \\
\hline $\mathrm{N}$ & 1.63 & 2.42 & - \\
\hline \multicolumn{4}{|c|}{$\mu \mathrm{g}$ Metal $\mathrm{g}^{-1}$ dry weight } \\
\hline $\mathrm{Rb}$ & $2.5 \pm 0.4$ & $54 \pm 4$ & $2.5 \pm 1.0$ \\
\hline $\mathrm{Cu}$ & $9.6 \pm 0.4$ & 9.7 & $140 \pm 30$ \\
\hline $\mathrm{Ag}$ & $0.28 \pm 0.03$ & $0.19 * 0.02$ & $0.78 \pm 0.04$ \\
\hline $\mathrm{Zn}$ & $79 \pm 3$ & $41 \pm 1$ & $90 \pm 1$ \\
\hline $\mathrm{Cd}$ & $0.30 \pm 0.01$ & $0.75 \div 0.14$ & $0.18 \pm 0.01$ \\
\hline $\mathrm{Ni}$ & $13 \pm 1$ & $2.4 \pm 0.1$ & $7.3 \pm 0.3$ \\
\hline $\mathrm{Al}$ & $580 \pm 80$ & $17 \pm 3$ & $200 \pm 60$ \\
\hline $\mathrm{Fe}$ & $1100 \pm 80$ & $160 \pm 30$ & $1700 \pm 250$ \\
\hline $\mathrm{Mn}$ & $9.4 \pm 0.3$ & $14 \pm 1$ & $15 \pm 1$ \\
\hline Caloric content & \multicolumn{2}{|c|}{ kcal $g^{-1}$ dry weight } & \\
\hline Total & 3.25 & 3.21 & - \\
\hline Available & 1.76 & 1.03 & - \\
\hline
\end{tabular}


same procedure and yielded metal concentrations within the ranges of certified values.

In the analysis of data, results were considered to be significant at the $95 \%$ confidence level.

\section{RESULTS}

Capitella capitata populations in the trays attained increased biomasses with increased food levels and, more generally, with increased level of detrital nitrogen (Fig. 1). This response is in agreement with previous work (Tenore, 1981). Standing crops at the end of the experiment represent increases in biomass of approximately $1600 \%$ at the lowest nitrogen ration and up to $7600 \%$ at the highest nitrogen ration. Because trays with larger populations also contain a substantially larger fraction of small juveniles (Tenore, 1977) the percent increases in numbers of individuals were even greater than the corresponding percent increases in biomass.

Concentrations of $\mathrm{Rb}, \mathrm{Ag}, \mathrm{Zn}, \mathrm{Cd}$, and $\mathrm{Ni}$ in the worms decreased significantly (one-way ANOVA and F-test of regression slopes) with increasing quantity of each detrital food (Fig. 2). The relative decreases were greatest for Ag (about $80 \%$ ), less for $\mathrm{Cd}$ and $\mathrm{Ni}$ (45-65\%), and least for $\mathrm{Rb}$ and $\mathrm{Zn}(30-40 \%)$. In general, worms cultured on equal rations (expressed as $\mathrm{g}$ of detritus $\mathrm{m}^{-2} \mathrm{~d}^{-1}$ ) of the two different detritus types did not have significantly different concentrations of these five metals (by t test analysis). Correlation coefficients for detrital nitrogen ration and metal concentrations in Capitella capitata ranged from -0.76 to -0.99 for worms cultured on Ascophyllum nodosum detritus and from -0.87 to -0.92 for worms cultured on Gracilaria foliifera detritus.

Concentrations of $\mathrm{Al}, \mathrm{Fe}$, and $\mathrm{Mn}$ in Capitella capitata generally increased with increasing ration of each detritus; however, the increases were not statistically significant at the $95 \%$ confidence level. Correlation coefficients for detrital nitrogen ration and metal concentrations in $C$. capitata ranged from +0.40 to +0.60 for worms cultured on Ascophyllum nodosum detritus and from +0.01 to +0.49 for worms cultured on Gracilaria foliifera detritus.

With the exception of copper, metal concentrations in these worms cultured on seaweed detritus were similar to metal concentrations in our control stock of Capitella capitata (Table 1). The control stock, which is 7 y old, is a dense population maintained on a highly nutritious diet (Gerber's mixed cereal). Concentrations of $\mathrm{Rb}, \mathrm{Ag}, \mathrm{Zn}, \mathrm{Cd}$, and $\mathrm{Ni}$ in the control stock are most nearly like those observed for worms receiving the highest detritus rations in this experiment. Concentra-

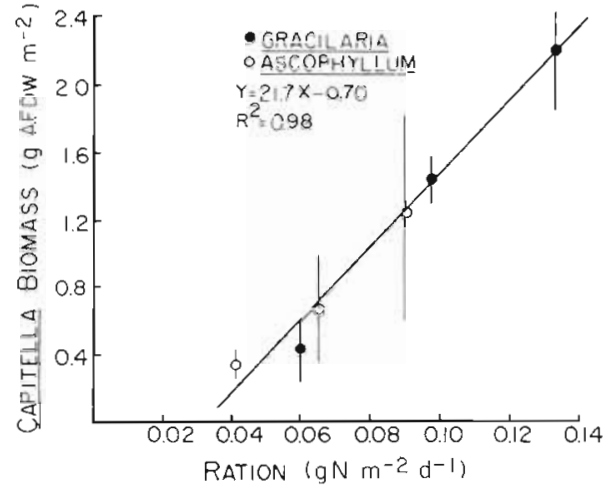

Fig. 1 Capitella capitata. Biomass at 3 food levels of 2 different types of detritus. Each point is the average for duplicate trays \pm one standard deviation

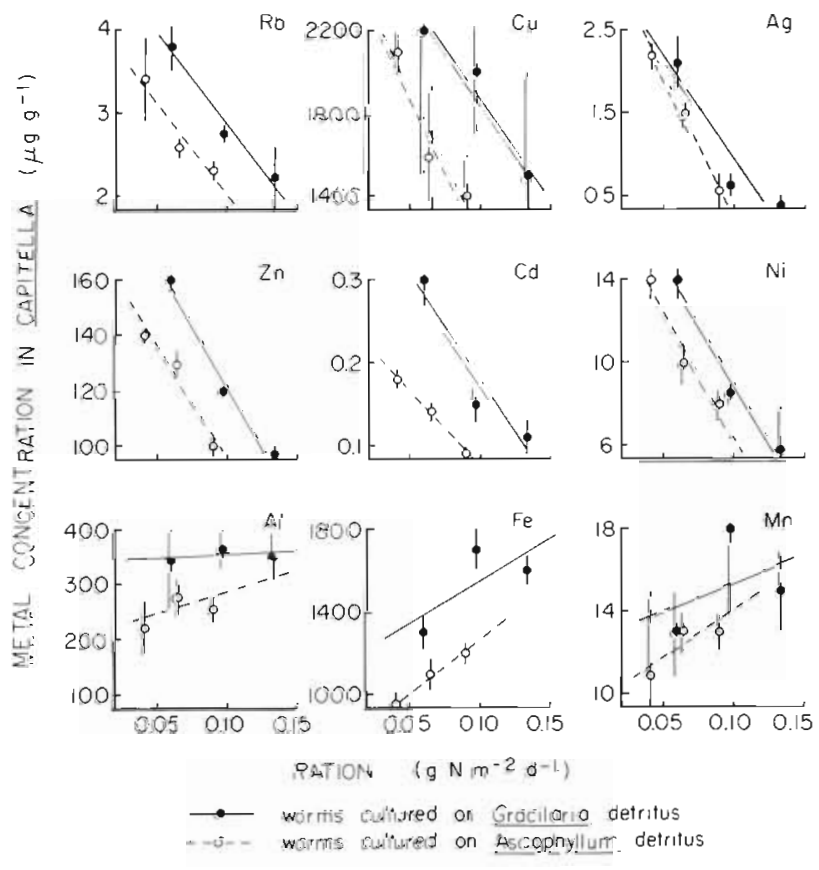

Fig. 2. Capitella capitata. Metal concentrations in worm populations as a function of detritus ration (expressed in nitrogen equivalents). Each point is the average of 4 metal determinations (on 2 replicate trays $\times 2$ samples per tray) \pm one standard deviation

tions of $\mathrm{Al}, \mathrm{Fe}$, and $\mathrm{Mn}$ in the control stock are in the midrange of values for worms in this study.

Copper concentrations reported in Figure 2 are about an order of magnitude higher than those of the control stock because of short-term copper contamination of one channel of our seawater system. Over a period of several weeks, Cu concentration in the seawater entering the culture trays rose from an ambient level of $0.2 \mathrm{ppb}$ to almost $2 \mathrm{ppb}$. Comparison of the numbers and biomass of Capitella capitata in this study with population growth data from previous work with this species (Tenore, 1977) indicated that the 
worms were not adversely affected by the surge in aqueous copper. The wide scatter in Cu concentrations in the worms associated with copper contamination makes the slopes of the regression lines in Figure 2 statistically insignificant, although the response similarity to $\mathrm{Rb}, \mathrm{Ag}, \mathrm{Zn}, \mathrm{Cd}$, and $\mathrm{Ni}$ is apparent

\section{DISCUSSION}

The rate of introduction of detritus into the benthic environment may effect metal concentrations in populations of benthic deposit feeders. Benthic organisms derive their body burden of metals from food, sediment, and water (Bryan, 1976); however, the relative importance of each of these three sources to metal uptake by deposit feeders like Capitella capitata is a question that has not been approached in this research, because, among other things we are dealing with population, not individual, responses. In our experiments, we examined metal uptake by populations of $C$. capitata which grew and stablized according to the level of detrital input, and it is toward this population response that we direct our efforts.

Detritus quantity may conceivably affect metal concentrations in deposit feeders in at least three ways:

(1) Detritus itself introduces metals into the benthic environment (Odum and Drifmeyer, 1978; Rice, 1979). Even after sedimentation, organic particulates undergo active metal exchange processes with vicinal waters. A recent review of investigations of metal uptake by biota using various feeding strategies has concluded that, for deposit feeders, assimilation of metals from aqueous solution is more important than assimilation from particulates (Jenne and Luoma, 1977); this conclusion, however, remains largely in the realm of speculation because of interspecific and experimental differences which make comparison of results difficult at best.

(2) Organic matter at the sediment-water interface may influence the bioavailability of metals in water and sediments to deposit feeders. Different types of marine detritus exhibit different metal exchange characteristics with seawater. Such differences may arise from differences in detritus decomposability, microbial activity, and metal reactivities and speciation (Rice, 1979). Furthermore, if respiration by aerobic organisms cannot keep pace with organic sedimentation, increased detritus input may promote anoxic conditions in which depression of $\mathrm{pH}$ and Eh may variously cause metal dissolution, precipitation, or solute speciation changes (Stumm and Morgan, 1970). Jenne and Luoma (1977) have suggested that organic and inorganic detrital particles exert their major effect on metal uptake by deposit feeders by regulating metal concentrations in vicinal waters through dissolutionprecipitation and sorption-desorption reactions.

(3) Under food limiting conditions the standing mass of organic detritus (or altermatively, the steadystate rate of detritus sedimentation) largely determines the detritivore population biomass. Metal concentrations in organisms are usually expressed as

$$
\text { Concentration }=\frac{\text { Mass of metal }}{\text { Biomass }}
$$

Studies of metal uptake by biota have traditionally focused on the quantity of metal (the numerator) in an individual (or, more specifically, the average metal concentration in a small number of 'replicate' individuals). At the population level, the standing crop of detritivores (the denominator) cannot be ignored. We will pursue this point further and assume that deposit feeders may derive their metal burden from some unspecified combination of organic detritus, sediment, and water sources.

Decreasing concentrations of $\mathrm{Rb}, \mathrm{Cu}, \mathrm{Ag}, \mathrm{Cd}, \mathrm{Zn}$, and $\mathrm{Ni}$ in populations of Capitella capitata with increasing food ration (or standing crop of C. capitata) may be attributed to competition for the available metal pool by larger numbers of individuals. As detritus ration increased, biomass production increased more rapidly than the average rate of uptake of each of these metals (except Ag) by C. capitata. At low areal food concentrations, deposit feeders rework their food supply more efficiently (presumably by increasing retention time in the gut or by coprophagy) than under conditions in which food is more plentiful (Levinton, 1980). Consequently, one might hypothesize that $C$. capitata cultured at low food levels assimilated metals more efficiently from the detritus and that detritus was a major direct source of assimilable metals. Such hypothesis seems untenable, however, because the populations in each tray were adjusted to a carrying capacity determined by detritus ration. Indeed, worm populations in trays receiving larger detritus rations (larger detritus-metal rations) had lower concentrations of these six trace metals. Although the standing crops of $C$. capitata were directly proportional to detritus ration, larger populations could more efficiently rework all three metal reservoirs in the trays, namely food, sediments and water.

Our conclusion that competition for the total pool of available metals controlled trace metal concentrations in Capitella capitata is especially supported by the data on silver uptake. Unlike the other metals, the mass of C. capitata-bound Ag (i.e. biomass $\times$ metal concentration in worms) did not vary between treatments. Of the six trace metals studied, Ag is present at the lowest concentrations in the two detritus and in 
seawater and sediments (Krauskopf, 1967). Dilute $\mathrm{HCl}$ leaching $\left(25^{\circ} \mathrm{C}, 3 \mathrm{~h}\right)$ of the sand from our culture trays yields leachable Ag concentrations of $0.004 \pm 0.001 \mathrm{~g}$ $\mathrm{g}^{-1}$; the next lowest leachable metal level was for $\mathrm{Cd}$ at $0.07 \pm 0.03 \mathrm{~g} \mathrm{~g}^{-1}$. These data suggest that the pool of available Ag was the smallest metal pool in our culture trays. Moreover, the invariance of the mass of C. capitata-bound Ag from tray to tray suggests that virtually all of the available Ag was taken up by the worms in each tray. The observations and the fact that worm metal concentration differences between highration trays and low-ration trays were greatest for Ag support our conclusion that trace metal concentrations in C. capitata were controlled by varying levels of competition for trace metal resources by populations of different sizes.

Differences in size distributions in Capitella capitata populations may account for the higher $\mathrm{Al}, \mathrm{Fe}$, and $\mathrm{Mn}$ concentrations in worms cultured at higher detritus rations. In our C. capitata cultures, larger populations invariably have a higher percent of small juveniles than smaller populations (Tenore, 1977); consequently, larger populations have a larger surface (exterior and gut) to volume (or biomass) ratio. Al, Fe, and $\mathrm{Mn}$ are far more abundant in sediments and estuarine waters than the six trace metals discussed previously, existing largely as amorphous hydroxides and clay colloids which are readily absorbed onto solid organic surfaces (Aston, 1978). Assuming that the uptake of these three metals by $C$. capitata was by sorption of colloids to body surfaces, the larger and statistically more juvenile populations would exhibit larger concentrations of these metals. However, because the abundance of $\mathrm{Al}, \mathrm{Fe}$, and $\mathrm{Mn}$ at the sediment-water interface made sample contamination virtually inevitable and because chemical assays of worms of different sizes were not performed, this conclusion is offered only as a reasonable hypothesis meriting further study.

We are only beginning to understand how nutritional parameters may control, or at least exert important effects upon, the trophic transfer of metals in natural and polluted detritus-based ecosystems. Estuarine sediments usually receive well under $50 \mathrm{mg}$ $\mathrm{N} \mathrm{m}^{-2} \mathrm{~d}^{-1}$ (Hargrave et al., 1976), a level at which Tenore (1981) reported nitrogen to be the major limiting factor, especially for detritus derived from seaweeds. So from the standpoint of food quantity it is not difficult to understand why benthos organisms are so susceptible to heavy metal pollution.

Yet, many more factors remain to be resolved. For example, in this study we have largely overlooked the role of bacteria, fungi, and other organisms involved in the complex detrital cycle. When food quantity or quality is high, microbial activity increases and recycling processes accelerate (Tenore et al., 1979). Nutrient enrichment, redox potential, and substrate degradability are important factors controlling gains and losses of metals from aging organic detritus (Rice, 1979), although we have only touched on their significance here. We emphasize the need for future systematic work on processes affecting chemical transfer at both the individual and the population levels and with benthos animals using other feeding strategies to compliment our work with Capitella capitata.

Acknowledgements. We thank Messrs. Kevin Briggs, Lee Bryant, Edward Chesney, Bruce Dornseif, and Randall Walker, who nursed, counted, and cleaned thousands of worms. Mr Ralph Smith assisted with analytical chemistry, and Ms. Katherine Holley with manuscript preparation. This research was supported by funds from the National Science Foundation, Grant number OCE77-20244.

\section{LITERATURE CITED}

Aston, S. R. (1978). Estuarine chemistry. In: Riley, J. P., Chester, R. (eds) Chemical oceanography, Vol. 7. Academic Press, London, New York, pp. 361-440

Bryan, G. W (1974). Adaptation of an estuarine polychaete to sediments containing high concentrations of heavy metals. In: Vernberg, F. J., Vernberg, W. B. (eds) Pollution and physiology of marne organisms. Academic Press. New York, London, pp. 123-135

Bryan, G. W. (1976). Some aspects of heavy metal tolerance in aquatic organisms. In: Lockwood, A. P. M. (ed.) Effects of pollutants on aquatic organisms. Cambridge University Press, Cambridge, pp. 7-34

Bryan, G. W., Hummerstone, G. G. (1971). Adaptation of the polychaete Nereis diversicolor to estuarine sediments containing high concentrations of heavy metals. I. General observations and adaptation to copper J. mar biol Ass. U.K. 51: 845-863

Bryan, G. W., Hummerstone, L. G. (1973 a). Adaptation of the polychaete Nereis diversicolor to estuarine sediments containing high concentrations of zinc and cadmium. J mar biol. Ass. U.K. 53: 839-857

Bryan, G. W., Hummerstone, L. G. (1973 b). Adaptation of the polychaete Nereis diversicolor to manganese in estuarıne sediments. J mar biol. Ass. U.K. 53: 859-872

Conover, R. J. (1962). Metabolism and growth in Calanus hyperboreus in relation to its life cycle. J. Cons. perm. int. Explor Mer 153: 190-197

Cross, F. A., Duke, T. W., Willis, J. N. (1970). Biogeochemistry of trace elements in a coastal plain estuary: distribution of manganese, iron, and zinc in sediments, water, and polychaetous worms. Chesapeake Sci. 11: 221-234

Darnell, R. M. (1967). Organic detritus in relation to the estuarine ecosystem. In: Lauff, L. G. (ed.) Estuaries. Publs Am. Ass. Advmt Sci. 83: 376-382

Hargrave, B. T., Phillips, G. A., Taguchi, S. (1976). Sedimentation measurements in Bedford Basin, 1973-74. Fish Mar. Ser. Rpt. 608: 1-129

Ireland, M. P. (1973). Result of fluvial zinc pollution on the zinc content of littoral and sub-littoral organisms in Cardigan Bay, Wales. Environ. Pollut. 4: 27-35

Jenne, E. A., Luoma, S. N. (1977). Forms of trace elements in soils, sediments, and associated waters: an overview of their determination and biological availability. In: Biolog- 
ical implications of metals in the environment. Proceedings of the 15th Annual Hanford Life Sciences Symposium. U.S. Energy Research and Development Administration, Springfield, Va., pp. 110-143

Krauskopf, K. B. (1967). Introduction to geochemistry, McGraw-Hill, New York

Levinton, J. S. (1980). Particle feeding by deposit-feeders: models, data, and a prospectus. In: Tenore, K. R., Coull, B C. (eds) Marine benthic dynamics. Univ. of South Carolina Press, Columbia, pp. 423-439

Mann, K. H. (1972). Macrophyte production and detritus food chains in coastal waters. Memorie Ist. ital. Idrobiol. 29 (Suppl.): 353-383

Odum, W. E., Drifmeyer, J. E. (1978). Sorption of pollutants by plant detritus: a review. Environ. Health Perspectives 27 133-137

Rice, D. L. (1979). Trace element chemistry of aging marine detritus derived from coastal macrophytes, Ph. D. Dissertation, Georgia Institute of Technology, Atlanta

Stumm, W., Morgan, J. J. (1970). Aquatic chemistry, WileyInterscience, New York

Suschenya, L. M. (1970). Food rations, metabolism, and growth of crustaceans. In: Steele, J. H. (ed.) Marine food chains. Univ. of California Press, Berkeley, pp. 127-141

Tenore, K. R. (1976). Food chain pathways in detrital feeding benthic communities: a review, with new observations on sediment resuspension and detrital recycling. [n: Coull, $\Gamma_{i}$. C. (ed.) Ecology of marine benthos, Lniv. of South Carolina Press, Columbia, pp. 37-53

Tenore, K. R. (1977). Growth of Capitella capitata cultured on various levels of detritus derived from different sources. Limnol. Oceanogr. 22: 936-941

Tenore, K. R. (1981). Organic nitrogen and caloric content of detritus. I. Utilization by the deposit-feeding polychaete, Capitella capitata. Estuar. coast. mar. Sci., in press

Tenore, K. R., Gopalan, U. K. (1974). Food chain dynamics of the polychaete Nereis virens cultured on animal tissue and detritus. J. Fish. Res. Bd Can. 31. 1675-1678

Tenore, K. R., Hanson, R. B., Dornseif, B. E., Wiederhold, C. N (1979). The effect of organic nitrogen supplement on the utilization of different sources of detritus. Limnol. Oceanogr 24: 350-355

Valiela, I., Banus, M. D., Teal, J. M. (1974). Response of salt marsh bivalves to enrichment with metal-containing sewage sludge and retention of lead, zinc, and cadmium by marsh sediments. Environ. Pollut. 7: 149-157

Windom, H. L., Cutshall, N. (1976). Atomic absorption spectrophotometry. In. Goldberg, E. D. (ed.) Strategics for marine pollution monitoring. Wiley-Interscience, New York, pp. 161-184

This paper was presented by Professor M. R. Carriker; it was accepted for printing on February 13, 1981 